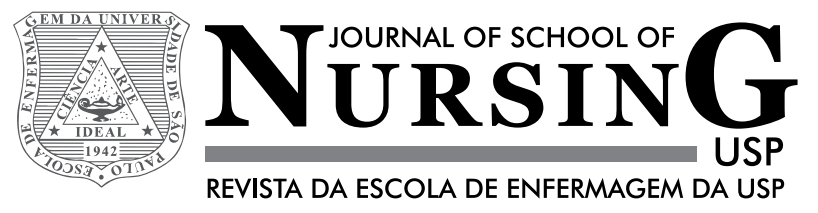

\title{
Self-care agency and quality of life in the preoperative period of coronary artery bypass graft surgery*
}

\section{Capacidade de autocuidado e qualidade de vida no pré-operatório de revascularização miocárdica \\ Capacidad de autocuidado y calidad de vida en el preoperatorio de revascularización miocárdica}

\author{
Raul Amaral de Araújo', Telma Marques da Silva', Vânia Pinheiro Ramos ${ }^{1}$
}

\section{How to cite this article:}

Araújo RA, Silva TM, Ramos VP. Self-care agency and quality of life in the preoperative period of coronary artery bypass graft surgery. Rev Esc Enferm USP. 2016;50(2):230-236. DOI: http://dx.doi.org/10.1590/S0080-623420160000200008

\begin{abstract}
* Extracted from the dissertation "Capacidade de autocuidado e qualidade de vida em indivíduos no pré-operatório de revascularização miocárdica”, Universidade Federal de Pernambuco, 2013.

${ }^{1}$ Universidade Federal de Pernambuco, Recife, PB, Brazil.
\end{abstract}

\begin{abstract}
Objective: To analyze basic self-care conditioning factors and quality of life associated with health, relating them to self-care capacity among individuals in the preoperative period of coronary artery bypass graft surgery. Method: Descriptive study with a quantitative approach, theoretically and methodologically anchored in the Self-care Deficit Nursing Theory. Data were collected between March and August 2013, using the Self-care Assessment Scale and the Medical Outcomes 36 Item Short Form Health Survey. Results: There was a correlation between self-care capacity and quality of life in the preoperative period of coronary artery bypass graft surgery. Conclusion: Among participants of this study, a reduction in quality of life may have occurred due to the presence of noncommunicable diseases; nevertheless, individuals sought the best ways to care for themselves.
\end{abstract}

\section{DESCRIPTORS}

Myocardial Revascularization; Self-Care; Quality of Life; Preoperative Care; Nursing Theory.

\section{Corresponding author:}

Raul Amaral de Araújo

Universidade Federal de Pernambuco,

Departamento de Prótese e Cirurgia

Buco-Facial

Av. Prof. Moraes Rego, 1235

Cidade Universitária

CEP 50670-901 - Recife, PE, Brazil Received: 12/09/2015

raul.amaral@ufpe.br 


\section{INTRODUCTION}

The incidence of noncommunicable diseases (NCD), along with an aging population, has caused an increase in demand for specialized services such as coronary artery bypass graft $(\mathrm{CABG})^{(1-3)}$, which dispense with the work by nurses in healthcare education of individuals who will be submitted to this procedure.

This work can be anchored in suitable nursing theories to attend individuals who are undergoing a phase characterized by anxiety, fear, and doubts when it comes to selfcare. In this scenario, it is worth highlighting the Self-care Deficit Nursing Theory, developed by Dorothea Orem ${ }^{(4-6)}$.

The above-mentioned theory is composed of three interrelated theoretical constructs: Self-care Theory, Self-care Deficit Theory, and Nursing System Theory ${ }^{(5)}$. These constructs are pervaded by theoretical concepts on self-care, Self-Care Agency (SCA), and Basic Conditioning Factors (BCF), focusing care on individuals, families, and communities ${ }^{(4-6)}$.

The theoretical framework developed by Dorothea Orem can support healthcare education strategies from the diagnostic phase onwards through interventions and their respective assessments. Their ultimate goal is human development and the best quality of life $\mathrm{f}^{(4-7)}$.

Studies that used this theoretical framework in their assumptions ${ }^{(1,8)}$ emphasized SCA, which is the ability of engaging in self-care actions, for health and well-being maintenance ${ }^{(5)}$. These goals were associated with HealthRelated Quality of Life (HRQoL) because it emphasizes the perception on health and well-being in research on the health-illness process ${ }^{(1,3,7-8)}$.

Additionally to the common synergy between SCA and HRQoL in maintaining health and well-being, both can be influenced by factors that are both intrinsic and extrinsic to human beings such as age, sex, and sociocultural and economic aspects. According to Dorothea Orem, these factors are called $\mathrm{BCF}^{(3,5,7)}$.

Thus, one understands that individuals' knowledge about SCA, HRQoL, and BCF during the CABG preoperative period is important and can support nurses' actions both in terms of healthcare education and in clinical practice ${ }^{(1-2,5,8)}$. However, studies that gather these three factors when it comes to health care are scarce.

In view of this problem, the objective of this study was to analyze basic conditioning self-care factors and health-related quality of life, associating them with selfcare agency among individuals in the preoperative period of coronary artery bypass graft surgery.

\section{METHOD}

This is a descriptive, cross-sectional study with a quantitative approach ${ }^{(9-10)}$, conducted at the Pronto-Socorro Universitário Cardiológico de Pernambuco Professor Luiz Tavares, Universidade de Pernambuco, an institution that belongs to the public healthcare system and is a benchmark for cardiology surgeries in the North and Northeast regions of Brazil. The hospital is located in the city of Recife, Pernambuco state.

The sample for this study was calculated by equation for the proportion of finite population studies, considering a previous study on this research site ${ }^{(11)}$. Participants were enrolled by nonrandom, intentional sampling ${ }^{(9-10)}$ and composed a 62-individual sample.

The study sample included individuals of both sexes who would submit to CABG for the first time as an elective surgery, between 50 and 70 years of age - the predominant age range for the researched population ${ }^{(11)}$. Individuals who had neurological or muscular damage, were undergoing psychotropic medical treatment, and had communication difficulties or inabilities were excluded from this study.

Data collection occurred between March and August 2013 and was individually undertaken in a private environment through interviews, due to low schooling among the researched population ${ }^{(11)}$.

Three questionnaires were used for data collection, and addressed: (1) socio-demographic and clinical information related to BCF; (2) HRQoL-Medical Outcomes 36 Item Short Form Health Survey (SF-36); (3) SCA - Appraisal of Self-Care Agency scale (ASA-scale). The SF-36 ${ }^{(12)}$ and the ASA-scale ${ }^{(13)}$ had been translated and validated for the Brazilian context.

Data related to $\mathrm{BCF}$ were collected through an instrument elaborated by the authors of this study and pre-tested to determine its usefulness in collecting valid data for this research ${ }^{(9)}$. This instrument consisted of information on age, sex, ethnicity/self-reported race, marital status, schooling, professional situation, monthly household income, and socioeconomic classification. Such information may have influenced both SCA and HRQoL ${ }^{(5,7)}$.

Socioeconomic classification was defined using Brazil's National Economic Classification Criteria, which estimates individuals' and families' purchasing power and divides them into five groups: A (highest status), B, C, $\mathrm{D}$, and $\mathrm{E}$ (lowest status). This estimate is based on the amount of items in the household and on the head of the household's educational level ${ }^{(14)}$.

Clinical data dealt with the comorbidities found; weight and height for the calculation of Body Mass Index (BMI), considering BMI $<25 \mathrm{~kg} / \mathrm{m}^{2}$ as no excess weight; $\mathrm{BMI} \geq 25 \mathrm{~kg} / \mathrm{m}^{2}$ and $<30 \mathrm{~kg} / \mathrm{m}^{2}$ as overweight; and $\mathrm{BMI} \geq 30 \mathrm{~kg} / \mathrm{m}^{2}$ as obesity ${ }^{(15)}$; and the clinical sign that triggered CABG.

Health-related quality of life was assessed through SF36 , a generic instrument consisting of 36 items grouped into eight domains (or sub-scales), which can be grouped into two components, creating a score between zero and 100 that demonstrates health perception ${ }^{(12)}$. Its validity is evidenced by Cronbach's alpha coefficients that varied between 0.59 and $0.85^{(16)}$.

Self-care agency, the dependent variable in this study, was assessed through the ASA-scale, which encompasses 24 items aimed at self-care operability and admits Likert 
responses. Its score ranges from 1 (strongly disagree) to 5 (strongly agree) $)^{(13)}$.

The translation and validation of the ASA-scale, named Scale to Assess Self-Care Capability (SASCC), showed a Cronbach's alpha coefficient of $0.85^{(13)}$. Among individuals with cardiovascular problems, this coefficient varied between 0.77 and $0.85^{(17)}$.

A database was designed using EPI INFO 3.5.2 software through double data entry for the validation of the data entered. Data were exported and analyzed by means of the Statistical Package for the Social Sciences (SPSS) version 18, using frequency, intervals (minimum and maximum value), means, and related standard deviations. Confidence intervals, SASCC mean scores, and the SF-36 eight domains were also described.

Cronbach's alpha served to assess the internal consistency of the SF-36 and SASCC to prove the reliability of these instruments in the researched sample ${ }^{(10)}$.

The chi-square test was used to compare the proportions between the studied BCF. Student's $t$ test and the Mann-Whitney test were used to compare variables between two groups. The Kruskal-Wallis test and the analysis of variance (ANOVA) were used for comparisons between three or more groups. These comparisons involved SASCC and the SF-36 eight domains scores.

Pearson's correlation coefficient was used to analyze the association between the SF-36 eight domains and the SASCC, and its significance was observed. The following correlation degrees were considered: perfect $(+1$ or -1$)$, strong ( +0.9 to +0.7 or -0.9 to -0.7$)$, moderate $(+0.6$ to +0.4 or -0.6 to -0.4$)$ and weak $(+0.3$ to +0.1 or -0.3 to -0.1$)^{(10)}$.

The Poisson regression model with robust variance was used to search for factors associated with the SASCC score. The selection of factors that independently helped explain the SCA was made through multiple regression analysis. The effect of each factor was expressed in terms of a Prevalence Ratio (PR) with a Confidence Interval (CI) of $95 \%$. The Wald Test was applied to determine statistical significance. A significance level of $5 \%(\mathrm{p}<0.05)$ was applied to all tests.

In this study, the four basic principles of bioethics were respected: autonomy, nonmaleficence, beneficence, and justice. This study was conducted after approval by the Research Ethics Committee of the Pronto-Socorro Universitário Cardiológico de Pernambuco Professor Luiz Tavares, Universidade de Pernambuco, under protocol no. 194.388. All the enrolled individuals accepted to participate voluntarily in the study, after having received clarifications and signing a free and informed consent form.

\section{RESULTS}

The mean age of the study participants was 60.69 $( \pm 6.71)$ years old and their mean monthly income was BRL 896.80 (Brazilian real). It is noteworthy that none of the participants belonged to socioeconomic classes $\mathrm{A}$ and E. The other studied BCF are shown in Table 1.
Table 1 - Basic conditioning self-care factors among study participants - Recife, Pernambuco, Brazil, 2013.

\begin{tabular}{|c|c|c|c|}
\hline Variable & $\mathbf{n}$ & $\%$ & p-value ${ }^{*}$ \\
\hline \multicolumn{4}{|l|}{ Age $(60.69 \pm 6.71)$} \\
\hline 50 to 60 years & 30 & 48.4 & \multirow{2}{*}{0.799} \\
\hline 61 to 70 years & 32 & 51.6 & \\
\hline \multicolumn{4}{|l|}{ Sex } \\
\hline Male & 42 & 67.7 & \multirow{2}{*}{0.005} \\
\hline Female & 20 & 32.3 & \\
\hline \multicolumn{4}{|l|}{ Ethnicity/self-reported race } \\
\hline White & 29 & 46.8 & \multirow{3}{*}{0.001} \\
\hline Black & 7 & 11.3 & \\
\hline Brown & 26 & 41.9 & \\
\hline \multicolumn{4}{|l|}{ Marital status } \\
\hline Married & 47 & 75.8 & \multirow{3}{*}{$<0.001$} \\
\hline Separated/divorced & 8 & 12.9 & \\
\hline Widowed & 7 & 11.3 & \\
\hline \multicolumn{4}{|l|}{ Professional status } \\
\hline Pensioner & 37 & 59.7 & \multirow{4}{*}{$<0.001$} \\
\hline Self employed & 8 & 12.9 & \\
\hline Employed & 12 & 19.4 & \\
\hline Unpaid & 5 & 8.1 & \\
\hline \multicolumn{4}{|l|}{ Schooling } \\
\hline No formal education & 9 & 14.5 & \multirow{3}{*}{$<0.001$} \\
\hline Elementary school & 41 & 66.1 & \\
\hline Secondary school & 12 & 19.4 & \\
\hline \multicolumn{4}{|l|}{ Socioeconomic class } \\
\hline B & 5 & 8.1 & \multirow{3}{*}{$<0.001$} \\
\hline C & 42 & 67.7 & \\
\hline $\mathrm{D}$ & 15 & 24.2 & \\
\hline \multicolumn{4}{|l|}{ Monthly household income ${ }^{+}$} \\
\hline$<$ BRL 678.00 & 13 & 21.0 & \multirow{3}{*}{$<0.001$} \\
\hline BRL 678.00 to $1,356.00$ & 23 & 37.1 & \\
\hline$>$ BRL 1,356.00 & 26 & 41.9 & \\
\hline
\end{tabular}

"Chi-square test. ${ }^{\dagger}$ In 2013, minimum wage in Brazil was BRL 678.00 per month. Observation: $(n=62)$.

Regarding clinical data, the participants' mean body mass index was $26.52( \pm 3.57) \mathrm{kg} / \mathrm{m}^{2}$ and the number of overweight participants $(50 \% ; \mathrm{p}=0.001)$ was significant. In terms of comorbidities, hypertension (78.18\%) and diabetes $(32.72 \%)$ stood out. Twenty-eight participants (50.90\%) stated they had the habit of smoking. Acute myocardial infarction was the main cause for CABG $(59.8 \%$; $\mathrm{p}<0.001)$.

The application of the SF-36 and the SASCC among research participants had 0.87 and 0.82 Cronbach's alpha coefficients, respectively. Regarding the SF-36, the rolephysical was the domain with the lowest score $(19.4 \pm 30.2)$, whereas mental health had the highest $(70.5 \pm 26.1)$. The mean SASCC score was 87.5 ( \pm 10.5). Additionally, there was a weak correlation between SF-36 domains and SASCC (Table 2). 
Table 2 - Descriptive analysis and correlation between SF-36 domains and self-care agency - Recife, Pernambuco, Brazil, 2013.

\begin{tabular}{|c|c|c|c|c|}
\hline Variable & Mean \pm SD (Interval) & $\mathrm{CI}(95 \%)$ & $r$ & p-value ${ }^{*}$ \\
\hline Self-care capacity & $87.5 \pm 10.5(44-95)$ & $85-90$ & & \\
\hline \multicolumn{5}{|l|}{ SF-36 domains } \\
\hline Physical functioning & $38.7 \pm 27.2(0-100)$ & $31.8-45.6$ & 0.166 & 0.197 \\
\hline Role-physical & $19.4 \pm 30.2(0-100)$ & $11.7-27.0$ & -0.049 & 0.708 \\
\hline Bodily pain & $48.3 \pm 30.7(0-100)$ & $40.5-56.1$ & -0.055 & 0.669 \\
\hline General health & $66.4 \pm 20.6(17-92)$ & $61.1-71.6$ & 0.061 & 0.638 \\
\hline Vitality & $58.1 \pm 29.0(0-100)$ & $50.7-65.4$ & 0.081 & 0.532 \\
\hline Social functioning & $43.5 \pm 31.6(0-100)$ & $35.5-51.6$ & 0.150 & 0.246 \\
\hline Role-emotional & $51.6 \pm 48.5(0-100)$ & $39.3-63.9$ & -0.062 & 0.630 \\
\hline Mental health & $70.5 \pm 26.1(8-100)$ & $63.9-77.1$ & 0.073 & 0.573 \\
\hline
\end{tabular}

'Pearson's correlation test.

Observing the distribution of the SASCC mean scores and SF-36 physical and mental components according to participants' age, sex, marital status, schooling, and socioeconomic class, no statistical significance was found (Table 3).

In the analysis by SF-36 domain, married participants scored higher in the role-emotional aspect (62.6 $\pm 46.7 ; \mathrm{p}=0.045)$. Individuals who finished secondary school had the highest score in social functioning $(58.3 \pm$ 32.6; $\mathrm{p}=0.038)$, similarly to those whose monthly income was higher than BRL 1,356.00 (54.3 $\pm 31.8 ; \mathrm{p}=0.033)$, and those who belonged to socioeconomic class B $(70.0$ $\pm 25.9 ; \mathrm{p}=0.008$ ).

In contrast, socioeconomic class $\mathrm{C}$ scored higher in physical functioning $(45.7 \pm 26.8 ; \mathrm{p}=0.006)$. There was no statistical significance among the other variables in terms of SF-36 domains and SASCC.

Nonetheless, SASCC scores were higher in the age range between 61 and 70 years old, among men, married participants, those whose schooling was higher, and among individuals who belonged to socioeconomic class D.

Table 3 - Association between basic conditioning factors with SF-36 components and self-care agency - Recife, Pernambuco, Brazil, 2013.

\begin{tabular}{|c|c|c|c|}
\hline Variable & Physical SF-36 component & Mental SF-36 component & Self-care agency \\
\hline \multicolumn{4}{|l|}{ Age } \\
\hline 50 to 60 years old & $45.0 \pm 28.3$ & $57,4 \pm 34,0$ & $85.4 \pm 10.6$ \\
\hline 61 to 70 years old & $41.5 \pm 26.2$ & $54.5 \pm 33.5$ & $88.3 \pm 6.5$ \\
\hline$p$-value & $0.337^{*}$ & $0.377^{*}$ & $0.200^{\ddagger}$ \\
\hline \multicolumn{4}{|l|}{ Sex } \\
\hline Male & $45.6 \pm 28.25$ & $57.1 \pm 34.65$ & $87.5 \pm 9.4$ \\
\hline Female & $38.1 \pm 24.22$ & $53.52 \pm 32.47$ & $85.8 \pm 7.6$ \\
\hline$p$-value & $0.337^{*}$ & $0.643^{*}$ & $0.503^{\ddagger}$ \\
\hline \multicolumn{4}{|l|}{ Marital status } \\
\hline Married & $43.8 \pm 27.4$ & $61.1 \pm 33.6$ & $88.1 \pm 7.8$ \\
\hline Separated/divorced & $45.7 \pm 32.2$ & $43.4 \pm 31.9$ & $81.6 \pm 12.2$ \\
\hline Widowed & $41.0 \pm 18.9$ & $58.2 \pm 33.7$ & $82.2 \pm 10.5$ \\
\hline$p$-value & $0.369^{+}$ & $0.267^{+}$ & $0.063^{\S}$ \\
\hline \multicolumn{4}{|l|}{ Schooling } \\
\hline No formal education & $34.0 \pm 18.5$ & $37.3 \pm 30.6$ & $89.6 \pm 4.8$ \\
\hline Elementary school & $45.7 \pm 27.7$ & $57.2 \pm 33.4$ & $85.3 \pm 8.2$ \\
\hline Secondary school & $41.5 \pm 28.0$ & $65.3 \pm 33.0$ & $90.5 \pm 11.7$ \\
\hline$p$-value & $0.435^{+}$ & $0.171^{+}$ & $0.116^{\S}$ \\
\hline \multicolumn{4}{|l|}{ Socioeconomic class } \\
\hline B & $44.0 \pm 28.6$ & $71.2 \pm 30.7$ & $89.6 \pm 4.8$ \\
\hline $\mathrm{C}$ & $46.3 \pm 27.8$ & $59.5 \pm 34.4$ & $85.3 \pm 8.2$ \\
\hline $\mathrm{D}$ & $43.0 \pm 21.8$ & $40.7 \pm 28.0$ & $90.5 \pm 11.7$ \\
\hline$p$-value & $0.381^{+}$ & $0.135^{+}$ & $0.116^{\S}$ \\
\hline
\end{tabular}

'Mann-Whitney Test. ${ }^{\dagger}$ Kruskal-Wallis Test. ${ }^{\ddagger}$ Student's $t$ Test. ${ }^{\S}$ Variance analysis. Observation: $(n=62)$. 
Analyzing Poisson's regression model for SASCC, the factors age $(\mathrm{p}=0.046)$, marital status $(\mathrm{p}<0.001)$, schooling $(\mathrm{p}=0.002)$, and monthly household income $(\mathrm{p}$-value $<0.001)$ were statistically significant.

In Table 4, however, the regression model was adjusted for SASCC according to age and monthly household income, after excluding schooling $(\mathrm{p}=0.390)$ and marital status $(\mathrm{p}=0.065)$. The 61 to 70 age range and monthly household income lower than BRL 678.00 were associated with a higher SASCC score.

Table 4 - Poisson's regression for self-care agency according to age and monthly household income - Recife, Pernambuco, Brazil, 2013.

\begin{tabular}{lccc}
\hline \multirow{2}{*}{ Variables } & \multicolumn{3}{c}{ Adjusted ratio } \\
\cline { 2 - 4 } & PR & Cl (95\%) & p-value* \\
\hline Age & & & \\
$\quad 50$ to 60 years old & 1.00 & - & - \\
$\quad$ 61 to 70 years old & 1.46 & $1.00-2.12$ & 0.048 \\
Monthly household income ${ }^{+}$ & & & \\
$\quad<$ BRL 678.00 & 1.80 & $1.26-2.58$ & 0.001 \\
BRL 678.00 to 1,356.00 & 1.08 & $0.76-1.54$ & 0.655 \\
$\quad>$ BRL 1,356.00 & 1.00 & - & - \\
\hline
\end{tabular}

Wald Test. 'In 2013, minimum wage in Brazil was BRL 678.00 per month.

\section{DISCUSSION}

The application of the SF-36 to assess quality of life pointed out that the mental component scored higher than the physical component and was associated with factors such as married individuals, higher schooling, higher monthly household income, and better socioeconomic classification.

This can show the relevance of these factors in possibly facing cardiovascular illnesses, associated with higher scores in the mental component ${ }^{(6,18)}$. In contrast, the lowest scores in the physical component, as seen in other studies ${ }^{(3,18)}$, may reflect the impact of cardiovascular illnesses on individuals' role-physical aspects.

In this study, a weak correlation between the SF-36 domains and the SASCC was found. Nonetheless, a study on people with NCD pointed out an association between the above-mentioned aspects and the best quality of life with higher self-care agency ${ }^{(1,8)}$.

Although the correlation seen in this study between quality of life and self-care agency was not strong ${ }^{(10)}$, it is possibly related to an active - albeit unhealthy - aging process in the researched sample. Hypothetically, living with NCD might harm quality of life.

However, the pursuit of better self-care would not be impossible even under the impact of a chronic illness. Therefore, there might be a relation between the self-care agency maintenance and development, an ability that is learned throughout life, with the subsequent demands of the health-illness process ${ }^{(1-2,17,19)}$.

In this scenario, it is worth underscoring the Self-care Deficit Nursing Theory for fostering maintenance and development of self-care practices, enhancing quality of life. The self-care promotion and resulting improvement in quality of life stands out in the researched sample, marked by aging and the presence of $\mathrm{NCD}$, despite the necessary understanding of the context where the nursing team would intervene $e^{(5,8,19)}$.

In view of the studied context, the SASCC score varied according to the basic self-care conditioning factors, among which age, marital status, schooling, and income stood out. After adjustment of the multivariate analysis, only age and income remained associated with the scores obtained through the SASCC.

These factors also stood out in studies that assessed selfcare agency among individuals with chronic illnesses ${ }^{(1,8,17)}$ and elderly individuals ${ }^{(19)}$, showing the importance of socioeconomic characteristics in the maintenance and development of self-care.

In this sense, age and income are factors that influence self-care maintenance and development ${ }^{(17)}$. In this study, the higher the age and the lower the income, the higher the SASCC score. Nevertheless, previous studies conducted in socioeconomic contexts that differed from the one in this study showed that younger ages and higher incomes were associated with higher scores in self-care agency assessment ${ }^{(1-2,8,19)}$.

A study conducted in Turkey among individuals with chronic obstructive pulmonary disease pointed to an association between higher ages and lower purchasing power and worse self-care agency ${ }^{(1)}$. Another study conducted in Holland with hospitalized elderly patients showed an association between higher ages and lower income and worse self-care ${ }^{(2)}$.

In a study with adults, which used advanced medical technology at homes such as mechanical ventilation and hemodialysis, it was observed that self-care agency was not associated with participants' ages in the regression analysis. Nevertheless, a negative linear relation occurred between self-care agency and age where higher self-care agency was associated with lower ages ${ }^{(8)}$.

Therefore, the association between age and income with SASCC scores among study participants may reflect strategies developed by each one of the individuals to confront NCD, beyond their social vulnerability ${ }^{(20-22)}$. Such vulnerability is aggravated by factors that may affect self-care agency, mainly low schooling, which makes self-care development and maintenance more difficult, but not impossible ${ }^{(1)}$.

Schooling had no statistical significance in this study, even though it was associated with self-care agency in other studies $^{(1-2,5,8)}$, which showed that individuals in preoperative CABG surgery with little schooling had a knowledge deficit on their own health condition and treatment ${ }^{(6)}$.

The unfavorable socioeconomic scenario, characterized by low schooling, poor income, and aging along with comorbidities creates obstacles to improved health condition ${ }^{(23)}$.

However, one can observe in the researched sample an ability to deal with such adversities, called self-care agency. These socioeconomic and clinical adversities may have produced adaptations and resulting personal and social growth, reflected in the maintenance of self-care agency in spite of poor quality of life. This may characterize a resilience state among the participants of this study ${ }^{(24)}$. 
Therefore, healthcare education actions are necessary to enhance self-care ${ }^{(25)}$, fostering better quality of life through a socioeconomic contextualization of such actions, which can be anchored in specific nursing theories ${ }^{(5,22,24)}$. There is also a need for research that corroborates the results found, broadening the discussion on self-care agency and its relation with basic selfcare conditioning factors and quality of life.

\section{CONCLUSION}

This study showed a weak correlation among its participants among the SF-36 domains and the SASCC. Nonetheless, the maintenance of self-care agency among higher ages and lower incomes was observed and constitutes a factor that may be unfavorable to self-care but that can be related to resilience among participants of this study in the researched context. Thus, although living with chronic-degenerative illnesses can lead to reduced quality of life, the individuals in this study sought the best ways to take care of themselves.

Further research addressing the concepts used in this study are necessary, as well as studies on other aspects of the Self-care Deficit Nursing Theory. It is important that future studies consider the aging population and living with chronic-degenerative illnesses, which require maintenance and development of self-care practices through healthcare education.

Nurses can use the Nursing Systems Theory, according to the Self-care Deficit Nursing Theory, in future research or interventions based on actions and interactions with individuals to foster the comprehensiveness of care practices in healthcare education. The objective of considering individuals as complex beings rather than mere information receivers is to empower their self-care and promote quality of life enhancements.

\section{RESUMO}

Objetivo: Analisar os fatores condicionantes básicos do autocuidado e a qualidade de vida relacionada à saúde, associando-os à capacidade de autocuidado em indivíduos no pré-operatório de revascularização miocárdica. Método: Estudo descritivo com abordagem quantitativa, ancorado teórico-metodologicamente na Teoria de Enfermagem do Déficit de Autocuidado. Coleta de dados realizada entre março e agosto de 2013, utilizando-se da Escala para Avaliação do Autocuidado e do Medical Outcomes 36 Item Short Form Health Survey. Resultados: Há correlação entre capacidade de autocuidado e a qualidade de vida no pré-operatório de revascularização miocárdica. Conclusão: Entre os participantes do estudo pode ocorrer uma redução na qualidade de vida, tendo em vista a convivência com doenças e agravos não transmissíveis e, mesmo assim, os indivíduos buscam as melhores maneiras de cuidar de si.

\section{DESCRITORES}

Revascularização Miocárdica; Autocuidado; Qualidade de Vida; Cuidados Pré-Operatórios; Teoria de Enfermagem.

\section{RESUMEN}

Objetivo: Analizar los factores condicionantes básicos del autocuidado y la calidad de vida relacionada con la salud, asociándolos a la capacidad de autocuidado en individuos en el preoperatorio de revascularización miocárdica. Método: Estudio descriptivo con abordaje cuantitativo, anclado teórica y metodológicamente en la Teoría Enfermera del Déficit de Autocuidado. Recolección de datos llevada a cabo entre marzo y agosto de 2013, utilizándose la Escala para Evaluación del Autocuidado y el Medical Outcomes 36 Item Short Form Health Survey. Resultados: Existe correlación entre la capacidad de autocuidado y la calidad de vida en el preoperatorio de revascularización miocárdica. Conclusión: Entre los participantes en el estudio puede ocurrir una reducción en la calidad de vida a la vista de la convivencia con enfermedades y agravios no transmisibles, pero aun así los individuos buscan las mejores maneras de cuidarse.

\section{DESCRIPTORES}

Revascularización Miocárdica; Autocuidado; Calidad de Vida; Cuidados Preoperatorios; Teoría de Enfermería.

\section{REFERENCES}

1. Yildirim A, Aşilar RH, Bakar N, Demir N. Effect of anxiety and depression on self-care agency and quality of life in hospitalized patients with chronic obstructive pulmonary disease: a questionnaire survey. Int J Nurs Pract. 2013;19(1):14-22.

2. Cramm JM, Hartgerink JM, Steyerberg EW, Bakker TJ, Mackenbach JP, Nieboer AP. Understanding older patients' self-management abilities: functional loss, self-management, and well-being. Qual Life Res. 2013;22(1):85-92.

3. Dessotte CAM, Dantas RAS, Schmidt A, Rossi LA. Health-related quality of life in patients admitted after a first episode of acute coronary syndrome. Rev Latino Am Enfermagem. 2011;19(5):1106-13.

4. Hewitt-Taylor J, Heaslip V, Rowe NE. Applying research to practice: exploring the barriers. Br J Nurs. 2012;21(6):356-9.

5. Taylor SG, Renpenning K. Self-care science, nursing theory, and evidence-based practice. New York: Springer; 2011.

6. Galdeano LE, Rossi LA, Dantas RAS. Deficient knowledge nursing diagnosis: identifying the learning needs of patients with cardiac disease. Int J Nurs Terminol Classif. 2010;21(3):100-7.

7. Polinder S, Haagsma JA, Belt E, Lyons RA, Erasmus V, Lund J, et al. A systematic review of studies measuring health-related quality of life of general injury populations. BMC Public Health [Internet]. 2010 [cited 2015 July 16];10:783. Available from: http://www.ncbi.nlm.nih. gov/pmc/articles/PMC3019196/

8. Fex A, Flensner G, Ek AC, Söderhamn O. Self-care agency and perceived health among people using advanced medical technology at home. J Adv Nurs. 2012;68(4):806-15. 
9. Polit DF, Beck CT. Fundamentos de pesquisa em enfermagem: avaliação de evidências para a prática da enfermagem. $7^{\mathrm{a}}$ ed. Porto Alegre: Artmed; 2011.

10. Agresti A, Finlay B. Métodos estatísticos para as ciências sociais. $4^{\mathrm{a}}$ ed. Porto Alegre: Penso; 2012.

11. Araujo NR, Araújo RA, Bezerra SMMS. Overweight and obesity repercussion in the postoperative of myocardial revascularization surgery. Rev Esc Enferm USP. 2014; 48(2):236-41.

12. Ciconelli RM, Ferraz MB, Santos W, Meinão I, Quaresma MR. Tradução para a língua portuguesa e validação do questionário genérico de avaliação de qualidade de vida SF-36 (Brasil SF-36). Rev Bras Reumatol. 1999;39(3):143-50.

13. Silva JV. Adaptação cultural e validação da escala para avaliar as capacidades de autocuidado. Rev Eletr Acervo Saúde . 2013;5(2):426-47.

14. Associação Brasileira de Empresas de Pesquisa. Critério de Classificação Econômica Brasil [Internet]. São Paulo: ABEP; 2012 [citado 2015 jul. 16]. Disponível em: http://www.abep.org/criterio-brasil

15. World Health Organization (WHO). Physical status: the use and interpretation of anthropometry. Geneva: WHO; 1995.

16. Weng LC, Dai YT, Huang HL, Chiang YJ. Self-efficacy, self-care behaviours and quality of life of kidney transplant recipients. J Adv Nurs. 2010;66(4):828-38

17. Sousa VD, Zauszniewski JA, Zeller RA, Neese JB. Factor analysis of the Appraisal of Self-care Agency Scale in american adults with diabetes mellitus. Diabetes Educ. 2008;34(1):98-108.

18. Horst R, Markou AL, Noyez L. Prognostic value of preoperative quality of life on mortality after isolated elective myocardial revascularization. Interact Cardiovasc Thorac Surg. 2012;15(4):651-4.

19. Karagozoglu S, Arikan A, Eraydin S. The fatigue and self-care agency levels of the elderly people staying in rest homes and the relation between these two conditions. Arch Gerontol Geriatr. 2012;54(3):e322-8.

20. Martin LG, Schoeni RF, Andreski PM, Jagger C. Trends and inequalities in late-life health and functioning in England. J Epidemiol Community Health. 2011;66(10):874-80.

21. Dowd JB, Zajacova A. Does self-rated health mean the same thing accross socioeconomic groups? Evidence from biomarker data. Ann Epidemiol. 2010;20(10):743-9.

22. Lima-Costa MF, Oliveira C, Macinko J, Marmot M. Socioeconomic inequalities in health in older adults in Brazil and England. Am J Public Health. 2012;102(8):1535-41.

23. Lopes MJ, Escoval A, Pereira DG, Pereira CS, Carvalho C, Fonseca C. Evaluation of elderly persons' functionality and care needs. Rev Latino Am Enfermagem. $2013 ; 21$ (n.spe):52-60.

24. Ferreira CL, Santos LMO, Maia EMC. Resilience among the elderly cared for by the primary healthcare network in a city of northeast Brazil. Rev Esc Enferm USP. 2012; 46(2):328-34.

25. Erdmann AL, Lanzoni GMM, Callegaro GD, Baggio MA, Koerich C. Understanding the process of living as signified by myocardial revascularization surgery patients. Rev Latino Am Enfermagem. 2013;21(1):332-9. 